\title{
LINGUISTIK FORENSIK, ALAT ANALISIS KEJAHATAN BERBAHASA
}

\author{
Wahyudi Rahmat \\ STKIP PGRI Sumatera Barat \\ wahyudirahmat24@gmail.com
}

Bahasa yang dituturkan oleh penutur bahasa mempunyai nilai-nilai dan norma dalam bahasanya. Bukan hanya berbahasa dalam forum resmi, tetapi juga dalam forum non resmi atau dalam kehidupan sehari-hari, baik dalm bentuk lisan ataupun lisan. Berbahasa tidak hanya memilahmilah bahasa sesuai kondisinya, namun juga mempertimbangkan norma sosial dan nilai-nilai dalam setiap pengucapannya.

Suatu nilai-nilai merujuk pada sesuatu yang bermakna baik. Sesuatu yang baik, tentunya akan melahirkan suatu padangan yang buruk. Dalam berbahasa, sesuatu yang buruk bisa saja terjadi, misalnya umpatan, ancaman, gertakan, ujaran persekusi, ujaran kebencian dan lain sebagainya. Beberapa waktu banyak sekali kebahasaan yang hadir dan berkembang di masyarakat. Malahan sesuatu untuk belum tentu layak untuk dikonsumsi oleh masyarakat umum, khususnya anak-anak usia sekolah. Hal ini berdampak pada penanaman nilai kognitif bernuansa negatif pada diri mereka. Kejahatan moral seperti ini merupakan aktivitas berbahaya yang dapat merugikan orang lain.

Berbahasa seperti ini dalam dunia linguistik forensik cenderung mengandung unsur kriminalitas karena secara tidak langsung bisa menyebabkan kerugian bagi petutur atau lawan tuturnya. Menurut paparan Dumas dalam Mcmenamin (2002:87) linguistik forensik itu berfokus pada bahasa hukum, interpretasi, bahasa ruang sidang, bahasa Inggris murni, pragmatik/kias, instruksi juri, bahasa dalam pengaturan hukum serta prosesnya, dan bahasa peringatan produk konsumen. Dapat dikatakan juga, bahwa dalam linguistik forensik tidak hanya fokus pada kasus yang diangkat dalam sebuah persidangan namun juga pada kasus atau masalah yang belum diangkat ke persidangan dan telah melanggar norma-norma sosial masyarakat seperti penghinaan, berbohong, peringatan, penipuan.

Melihat keadan bahasa Indonesia saat sekarang ini yang telah banyak dimarkahi salah oleh sebagian orang, maka linguistik forensik dirasa perlu untuk dipakai oleh beberapa ahli bahasa. Pertimbanganya adalah keilmuan ini merupakan ilmu multi disipliner, yakni Ilmu bahasa dan ilmu hukum. Linguistik forensik adalah salah satu cabang linguistik baru. Linguistik forensik adalah ilmu multidisiplin karena analisisnya dapat diperbantukan dengan bidang ilmu lain seperti ilmu bahasa, ilmu hukum, ilmu kejiwaan, ilmu sosial dan bidang ilmu lain yang mampu memecahkan suatu masalah kriminal. Seperti yang disebutkan oleh Olsson (2008:3) linguistik forensik adalah hubungan antara bahasa dengan penegakan, masalah, perundang-undangan, perselisihan atau proses dalam 
hukum yang berpotensi melibatkan beberapa pelanggaran terhadap hukum atau keharusan untuk mendapatkan penyelesaian hukum.

Dalam sejarahnya, bidang ini telah disebut linguistik forensik sejak 1980. Linguistik forensik merupakan ilmu multidisiplin berasal dari linguistik dan hukum yang telah dikembangkan di Amerika dan Eropa sejak tahun 1997 (Momemi, 2011). Sejak itu, ahli bahasa menawarkan bukti mereka di pengadilan untuk mendeteksi realitas dan lebih berhati-hati penghakiman sebuah kasus.

Kejahatan yang terbentuk melalui bahasa adalah kejahatan yang dapat dipelajari dari sudut pandang linguistik. Kejahatan berbahasa tersebut dapat berupa penghinaan, ancaman, penipuan, bahasa palsu (pragmatik). Bahkan kejahatan seperti pencurian, penculikan dan pembunuhan yang melibatkan bahasa sebelum terjadinya kejahatan, dapat dianggap sebagai kejahatan berbahasa. Linguistik forensik biasanya digunakan dalam menganalisis aksi kejahatan yang berkaitan dengan penggunaan berbahasa, baik itu lisan maupun tulisan. Coulthard and Johnson (2010) menyebutkan bahwa linguistik forensik itu dapat memfokuskan kajiannya pada bahasa proses hukum dan bahasa sebagai bukti, baik lisan maupun tulisan. Untuk melihat sebuah kasus linguistik forensik, dapat dipakai klasifikasi teks untuk mengetahui bentuk linguistik sebagai bukti investigasi fungsi teks tersebut (Rahmat, 2014).

Di Amerika linguistik forensik sudah masiv dipakai untuk menyelesaikan banyak masalah, seperti beberapa kasus persidangan yang menggunakan ahli bahasa. Smith (2002) menyebutkan bahwa hal pokok yang belum menjadi fokus seseorang dalam meneliti suatu tindak kriminal adalah meneliti bahasa seseorang. Perilaku pelaku di TKP (tempat kejadian perkara) dan interaksi dengan para korban dapat membantu mengungkapkan motif kejahatan. Hal ini juga dapat membantu peneliti membangun sebuah deskripsi kepribadian dan karakteristik pelaku. Kepribadian dan karakteristik pelaku tersebut dapat dilihat dalam bahasa-bahasa pelaku tersebut. Penulis sependapat dengan Smith yang menyebutkan bahwa untuk meneliti pengancam dapat diketahui dari bahasa yang ia gunakan dan dari bahasa tersebut, seperti FBI yang dapat mengungkap motif pelaku dalam aksi kejahatannya.

Aplikasi linguistik forensik juga telah memasuki Indonesia. Sudah banyak penelitianpenelitian dan tulisan mengenai bentuk aplikasi atau pendekatan yang digunakan melalui linguistik forensik. Melihat tersebut, maka dapat disimpulkan linguistik forensik adalah sebuah ilmu yang dapat mengungkap suatu kejahatan berbahasa. Baik kejahatan berbahasa berwujud lisan ataupun tulisan.

\section{Referensi}


Coulthard, Malcolm \& Alison Johnson. 2010. The Routledge Handbook of Forensic Linguistics. USA: Milton Park, Abingdon

McMenamin, G. 2002. Forensic Linguistics - Advances in Forensic Stylistics. Florida: CRC Press

Momeni, N. 2011. "Linguistic Analysis of Language Crimes: Forensic Linguistics Approach". Jurnal : Theory and Practice in Language Studies, Vol. 2, No. 6, pp. 1263-1269, June 2012. Tehran: Tarbiat Modares University. Diakses dalam www.pnri.go.id

Olsson, Jhon. 2008. Forensic Linguistics: Second Edition. London: Continuum International Publishing Group

Rahmat, W. (2014). Bahasa Ancaman dalam Teks Kaba Sabai Nan Aluih Berbasis Pendekatan Linguistik Forensik. Arbitrer, 2(7).

Smith, Sharon S. Shuy \& Roger W. 2002. "Forensic psycholinguistics: Using language analysis for identifying and assessing offenders". Jurnal : FBI Law Enforcement Bulletin. Diakses dalam www.pnri.go.id 